\title{
Does managerial ability enhance earnings quality? The moderating role of corporate governance quality and ownership concentration
}

Fitri Romadhon ${ }^{1 *}$, Indra Wijaya Kusuma ${ }^{2}$

${ }^{1}$ Department of Accounting, Faculty of Economics and Business, Universitas Internasional Semen Indonesia, Gresik, Indonesia

${ }^{2}$ Department of Accounting, Faculty of Economics and Business, Universitas Gadjah Mada, Yogyakarta, Indonesia

*Corresponding Author(s) Email: fitri.romadhon@uisi.ac.id

\section{ABSTRACT}

Earnings quality is information that can be determined by various factors, one of which is managerial ability. Thus, management quality itself can have a positive or negative impact on earnings quality, depending on the factors that affect their relationships. This study was conducted to reexamine the effect of managerial ability on earnings quality by including corporate governance quality and ownership concentration as factors that are expected to be able to explain the inconsistencies in the results of previous studies. This study used the data of manufacturing companies listed on the Indonesia Stock Exchange in 2010-2016 as study sample with total observations were 253. The analysis technique used for hypothesis testing was a multiple linear regression analysis. This study succeeds in proving the moderation role of governance quality in strengthening the relationship between managerial ability and earnings quality. However, the role of ownership concentration as moderator factors failed to prove in this study. Interestingly, there is a negative effect between managerial ability and earnings quality. The opportunistic actions taken by managers who want to meet their performance targets was considered as the reason of the negative effect between managerial ability and earnings quality.

Keywords: Managerial Ability; Earnings Quality; Ownership Concentration; Governance Quality; Agency Theory
JEL Code:

M40, M41, G32, G34

DOI:

10.31106/jema.v17i2.6067

Article History:

Received 2020/02/03

Reviewed 2020/06/03

Revised 2020/06/11

Accepted 2020/11/12

Licensed:

CC-BY 
Does managerial ability enhance earnings quality? The moderating role of corporate governance quality and ownership concentration by Fitri Romadhon, Indra Wijaya Kusuma

\section{Introduction}

Earnings quality is one of the important information regarding a company's financial performance that is relevant for certain decision-making (Dechow et al., 2010). This statement is in line with the study of (Harris et al., 2019) which proved that investors can also experience earning fixation, i.e. the tendency to be fixated on earnings information without considering other relevant information.

Studies on earnings quality have also experienced very significant growth during the last two decades, especially the ones regarding the definition, measurement, and determinants of earnings quality (Dechow et al., 2010; DeFond, 2010; Demerjian et al., 2013; Dichev et al., 2013). While the majority of earning quality has focused on corporate characteristics, corporate governance, and audit quality (Pomeroy \& Thornton, 2008; Gul et al., 2009; Dechow et al., 2010; Bryan et al., 2013). Dichev et al. (2013) identified the importance of the role of management in generating company earnings quality. Numerous empirical studies have found that managerial ability has a positive effect on earnings quality as the more-able managers are believed to be more able to deal with the complexities of operational decision making, generate more sales revenue, and enhances firm performances (Pan et al., 2015; Bonsall et al., 2017; Huang \& Sun, 2017). However, Lobo \& Zhou (2001), Shette et al. (2016), and Prakoso \& Purwanto (2017) warned that greater earning management with the more opaque information environment may resulting in giving the managers opportunities to act opportunistically. Murniati et al. (2019) stated that earning management behavior could not be considered as profit manipulation as long as the process was done by following accounting standards.

The result of a previous study regarding the role of managers and earnings quality indicates a study gap between managerial ability and earnings quality and raises the possibility of other factors that can explain the relationship between managerial ability and earnings quality, such as the supervisory function of managers. Good supervisory mechanisms, such as corporate governance quality, are expected to limit the opportunistic behavior of managers in carrying out their roles so that the quality of financial reports can improve (Mersni \& Ben Othman, 2016; Marchini et al., 2018). Apart from supervision carried out through the corporate governance mechanism, several other mechanisms are important to consider, one of which is a company's ownership concentration (García Lara et al., 2009; Bao \& Lewellyn, 2017; Lassoued et al., 2018). 
Referring to the inconsistency of the effect of managerial ability and earnings quality and study that emphasizes the importance of supervisory mechanisms, which stated that an effective control system through representatives of the owners, the board of commissioners, and the audit committee can prevent agency conflicts that may arise when managers carry out their duties, it is important to re-examine whether differences in study results can be caused by other factors such as supervisory factors. Besides, a study on governance as a supervisory mechanism is also important to review due to the phenomenon of corporate governance strengthening that is being intensified by regulators, particularly within the context of Indonesia. Therefore, this study was conducted to re-examine the effect of managerial ability on earnings quality by including corporate governance quality and ownership concentration as factors that are expected to be able to explain the inconsistencies in the results of previous studies.

\section{Literature Review}

\section{Agency Theory}

Agency theory is a theory that explains the agency relationship between one or more principal parties and other parties, namely agents who carry out a series of tasks that have the potential to create conflicts of interest (Jensen \& Meckling, 1976). Conflicts of interest between the principal and the agent can be caused by the role of the manager as an agent who has an incentive to obtain benefits and can harm the principal. To minimize these conflicts, the principal can supervise and provide incentives to agents (Jensen \& Meckling, 1976). Monitoring mechanisms for agents can be carried out in several ways, i.e. natural mechanisms, such as capital market pressures and corporate ownership structures, and institutional mechanisms, such as corporate governance (García Lara et al., 2009). Apart from corporate governance, efforts to reduce agency conflicts can also be carried out through supervision by the majority shareholder (Shleifer \& Vishny, 1997).

\section{Managerial Ability and Earnings Quality}

Bertrand \& Schoar (2003) concluded that managers have an important role in company performance. Several studies have shown inconsistent results related to managerial ability and earnings quality, such as Bolmiri et al. (2016) and Demerjian et al. (2013) who concluded that more capable managers can produce higher earnings quality. While other studies such as those by Djuitaningsih \& Rahman (2012) show different results, which 
Does managerial ability enhance earnings quality? The moderating role of corporate governance quality and ownership concentration by Fitri Romadhon, Indra Wijaya Kusuma

indicate that the more reputable managers are, the more competent they are to produce fewer earnings quality.

Ge et al. (2011) added that managerial ability has a positive influence on earnings quality since they can determine policies that will affect the company, such as policies in discretionary accruals. Therefore, in addition to the positive influence, the negative impact of managerial ability can also occur when managers are motivated to meet performance expectations in various ways, including by managing earnings. Based on the explanation of a manager's influence on earnings quality, which can be positive or negative, the first hypothesis can be drawn as follows.

$\mathrm{H}_{1}$ : Managerial ability affects earnings quality.

\section{Managerial Ability, Corporate Governance Quality, and Earnings Quality}

The inconsistency of the relationship between managerial ability and earnings quality, as stated in the previous section, means that a capable manager does not necessarily guarantee the success of the company's performance because other factors can trigger these two factors, one of which is the supervisory mechanism by corporate governance quality (García Lara et al., 2009; Mersni \& Ben Othman, 2016; Marchini et al., 2018). Piot \& Janin (2007) concluded that the existence of an audit committee as part of corporate governance is proven to limit earnings management, something that may be done by managers. This study is in line with the research of Cohen et al. (2014) and Klein (2002) which explained that the existence of an audit committee with certain expertise and a more independent board structure can improve the quality of financial reporting or decrease earnings management.

Some of these studies indicate that corporate governance, apart from having a supervisory role, also serves as a complement and support that strengthens the role of managerial ability. This is in line with Crossland \& Hambrick (2007) study which shows that manager discretion is also determined by environmental conditions or organizational factors such as governance. This statement can be interpreted that companies with capable managers will be able to generate earnings quality if supported by reinforcing factors. Based on this explanation, a second alternative hypothesis can be formulated, i.e. that governance quality can strengthen the relationship between managerial ability and earnings quality.

$\mathrm{H}_{2}$ : Corporate governance quality can strengthen the relationship between managerial ability and earnings quality. 


\section{Managerial Ability, Ownership Concentration, and Earnings Quality}

Conflicts of interest between agents and principals are expected to decrease in companies with concentrated ownership because it can facilitate more effective supervision and access to information (Le Breton-Miller et al., 2015). The effect of ownership concentration can also be viewed from the alignment hypothesis, namely the ability to control shareholders to align their interests by monitoring and limiting opportunistic behavior, such as the manipulation of financial performance (Fan \& Wong, 2002; Huang \& Xue, 2016; Bao \& Lewellyn, 2017; Lassoued et al., 2018). Another previous study by Li et al., (2015) also confirms that ownership concentration has an important role in moderating the effectiveness of governance so that it can affect company performance. Conclusions about the negative impact of concentrated ownership are not always proven, because it is necessary to pay attention to the context in which the company under study is located, the party who owns the majority of the shares, or the company's ownership structure.

Within the context of Indonesia, several studies have shown that company ownership that is concentrated in certain parties has a positive effect on performance. One example is the research of Susilawati \& Rakhman (2018) which concluded that companies whose majority shares are owned by the government can produce a financial performance that is equivalent to that of private companies. Based on the descriptions of these various studies, it can be assumed that the effect of ownership concentration may be different if it refers to the characteristics of companies in Indonesia, as managers can work more efficiently and produce more reliable financial information.

$\mathrm{H}_{3}$ : Ownership concentration can strengthen the relationship between managerial ability and earnings quality.

\section{Methods}

Figure 1. Research Framework

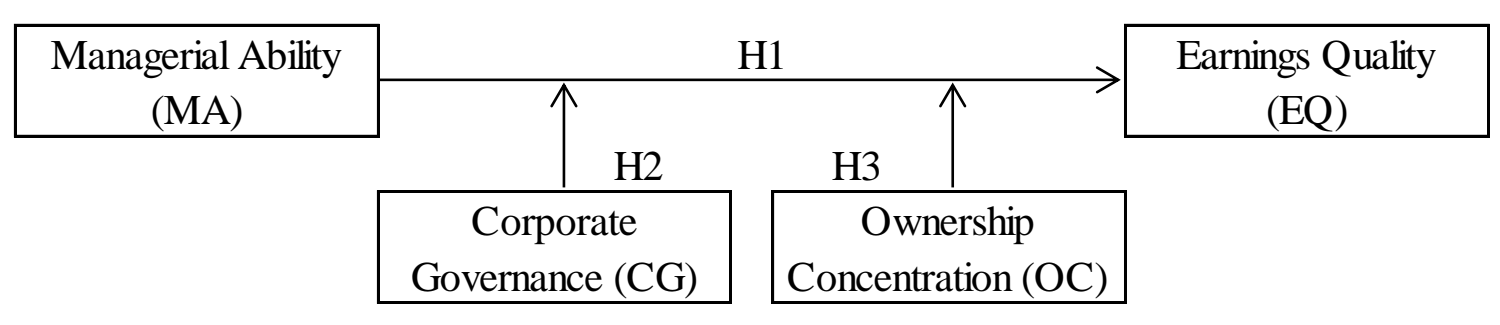

The design research of this study was a quantitative approach (empirical study) as the objective of this study which aims to test hypotheses based on theory, facts, and previous research through statistical procedures. This study was conducted to re-examine the effect of 
Does managerial ability enhance earnings quality? The moderating role of corporate governance quality and ownership concentration by Fitri Romadhon, Indra Wijaya Kusuma

managerial ability on earnings quality by including corporate governance quality and ownership concentration as factors that are expected to be able to explain the inconsistencies in the results of previous studies.

The variables used in this study include three types of variables. First is the dependent variable, namely earnings quality, which is measured by using accrual quality following the modified research (Dechow \& Dichev, 2002; McNichols, 2002). Second is the independent variable, namely managerial ability, which is measured based on the MA (managerial ability) score (Demerjian et al., 2013). Lastly is two moderating variables, namely corporate governance quality, which refers to the studies of Bertrand \& Mullainathan (2003) and García Lara et al., (2009) is measured based on the aggregate measurement index of the average of five components of governance, and ownership concentration, which is measured based on the percentage of shares owned by the largest shareholders (Demsetz \& Lehn, 1985; Sousa \& Galdi, 2016). Also, this study used four control variables, including company size, book-tomarket equity ratio, sales growth, and leverage. The use of control variables was intended to control or complete the causal relationship between variables or ensure that the results of the study are not biased if they do not include several control variables.

Table 1. The Definition of Variables

Variable

Earnings Quality

Managerial ability

Corporate Governance

Quality

Ownership

Concentration

Company Size

Book-to-market Equity

Sales growth

Leverage
Definition

Accrual quality obtained from the error value in the equation below $\Delta W C_{t}=\alpha+\beta_{1} C F O_{t-1}+\beta_{2} C F O_{t}+\beta_{3} C F O_{t+1}+\beta_{4} \Delta R E V_{t}+\beta_{5} P_{P E}+\varepsilon_{t}$

MA score of DEA software with output (sales) and input (total assets, number of workers, days COGS in inventory, days sales outstanding)

Average of the five components of corporate governance (total audit committee, a total board of commissioners, frequency of board meetings, frequency of audit committee meetings, and audit quality),

$\%$ of shares owned by the largest shareholder

Natural log of total assets

Book Value of Equity / Market Value of Equity

$\left(\right.$ Sales $_{\mathrm{t}}-$ Sales $\left._{\mathrm{t}-1}\right) /$ Sales $_{\mathrm{t}-1}$

Total Debt / Total Equity

The population of this study was manufacturing companies listed on the Indonesia Stock Exchange. The sample used was selected through a purposive sampling technique. Following are the sample selection criteria: 1) The manufacturing company was listed on the Indonesia 
Stock Exchange during 2011-2015, 2) There was a minimum of five companies in each manufacturing sub-industry, 3) The company published a complete annual report, and 4) The company had the necessary data and information and was related to the variables to be studied. 253 observations were obtained, covering 12 sub-industries.

Table 2. Sample Selection

\begin{tabular}{lc}
\hline Criteria of Sample Selection & Total \\
\hline Manufacturing companies in the 5 year research period (2011-2015) & 865 \\
Did not meet the minimum requirements for each sub-industry & $(288)$ \\
Did not publish an annual report & $(80)$ \\
Did not have complete data and information & $(239)$ \\
Total sample during the observation period & 258 \\
Outlier & $(5)$ \\
Final total observations & 253 \\
\hline
\end{tabular}

The type of data used was secondary data obtained through several sources, namely the OSIRIS database and company annual reports. The first statistical analysis performed was classical assumption tests and followed by hypothesis testing. The classical assumption test used consisted of a normality test, heteroscedasticity test, autocorrelation test, and multicollinearity test. In the independent variable testing, moderation was carried out on the dependent variable using multiple regression analysis with the OLS method. This analysis served to test the effect of independent variables on the dependent variable, including examining the relationship between variables so that a model that was appropriate to the conditions faced by the researcher could be obtained. Three regression models are used to answer the proposed hypotheses of this study.

$$
\begin{aligned}
\mathrm{EQ}_{\mathrm{i}, \mathrm{t}}= & \beta_{0}+\beta_{1} \mathrm{MA}_{\mathrm{i}, \mathrm{t}}+\beta_{2} \mathrm{Size}_{\mathrm{i}, \mathrm{t}}+\beta_{3} \mathrm{BM}_{\mathrm{i}, \mathrm{t}}+\beta_{4} \mathrm{SG}_{\mathrm{i}, \mathrm{t}}+\beta_{5} \mathrm{LEV}_{\mathrm{i}, \mathrm{t}}+\varepsilon_{\mathrm{i}, \mathrm{t}} \\
\mathrm{EQ}_{\mathrm{i}, \mathrm{t}}= & \beta_{0}+\beta_{1} \mathrm{MA}_{\mathrm{i}, \mathrm{t}}+\beta_{2} \mathrm{CG}_{\mathrm{i}, \mathrm{t}}+\beta_{3}\left(\mathrm{MA}_{\mathrm{i}, \mathrm{t}} * \mathrm{CG}_{\mathrm{i}, \mathrm{t}}\right)+\beta_{4} \mathrm{Size}_{\mathrm{i}, \mathrm{t}}+\beta_{5} \mathrm{BM}_{\mathrm{i}, \mathrm{t}}+\beta_{6} \mathrm{SG}_{\mathrm{i}, \mathrm{t}} \\
& +\beta_{7} \mathrm{LEV}_{\mathrm{i}, \mathrm{t}}+\varepsilon_{\mathrm{i}, \mathrm{t}} \\
\mathrm{EQ}_{\mathrm{i}, \mathrm{t}}= & \beta_{0}+\beta_{1} \mathrm{MA}_{\mathrm{i}, \mathrm{t}}+\beta_{2} \mathrm{OC}_{\mathrm{i}, \mathrm{t}}+\beta_{3}\left(\mathrm{MA}_{\mathrm{i}, \mathrm{t}} * \mathrm{OC}_{\mathrm{i}, \mathrm{t}}\right)+\beta_{4} \mathrm{Size}_{\mathrm{i}, \mathrm{t}}+\beta_{5} \mathrm{BM}_{\mathrm{i}, \mathrm{t}}+\beta_{6} \mathrm{SG}_{\mathrm{i}, \mathrm{t}} \\
& +\beta_{7} \mathrm{LEV}_{\mathrm{i}, \mathrm{t}}+\varepsilon_{\mathrm{i}, \mathrm{t}}
\end{aligned}
$$

Annotation:

EQ : Quality of accruals for company $\mathrm{i}$ in year $\mathrm{t}$

MA : Managerial ability of company $i$ in year $t$

$\mathrm{CG}$ : Corporate governance of company $\mathrm{i}$ in year $\mathrm{t}$

OC : Ownership concentration of company $i$ in year $t$ 
Does managerial ability enhance earnings quality? The moderating role of corporate governance quality and ownership concentration by Fitri Romadhon, Indra Wijaya Kusuma

Size : Size of company $\mathrm{i}$ in year $\mathrm{t}$

BM : Book-to-market equity ratio of company $\mathrm{i}$ in year $\mathrm{t}$

$\mathrm{SG} \quad$ : Sales growth ratio of company $\mathrm{i}$ in year $\mathrm{t}$

LEV : Leverage ratio of company $i$ in year $t$

To ensure the robustness of the research model, the model should pass all classical assumptions testing such as normality, heteroscedasticity, autocorrelation, and multicollinearity. Table 3 shows that the model pass the autocorrelation assumption as the results of the Durbin Watson testing shows that the score of Durbin Watson was in the range of $\mathrm{du}<\mathrm{dw}<\mathrm{d}$-du values. All three models were also distributed normally as it has a significant value that higher than 0.05 for the Kolmogorov-Smirnov test.

Table 3. Autocorrelation and Normality Results

\begin{tabular}{lccccc}
\hline $\begin{array}{l}\text { Autocorrelation } \\
\text { / Normality Test }\end{array}$ & Model 1 & Model 2 & Model 3 & Criteria & Decision \\
\hline Durbin Watson & $\mathrm{dU}=1.828$ & $\mathrm{dU}=1.841$ & $\mathrm{dU}=1.842$ & $\mathrm{dU}<\mathrm{dW}<4-\mathrm{dU}$ & Pass \\
$\begin{array}{l}\text { Kolmogrov- } \\
\text { Smirnov }\end{array}$ & $\mathrm{dW}=2.139$ & $\mathrm{dW}=2.088$ & $\mathrm{dW}=2.157$ & & \\
\hline
\end{tabular}

The Glejser test results (Table 4) show that none of the variables in this study was significantly influenced the dependent variable of residual absolute as it has a significant value that higher than 0.05 . Therefore, it can be concluded that the three regression models did not have heteroscedasticity symptoms.

Table 4. Heteroscedasticity Results

\begin{tabular}{lcccccc}
\hline \multirow{2}{*}{ Variables } & \multicolumn{2}{c}{ Model 1 } & \multicolumn{2}{c}{ Model 2 } & \multicolumn{2}{c}{ Model 3 } \\
& Coef. & Sig. & Coef. & Sig. & Coef. & Sig. \\
\hline MA & -0.051 & 0.482 & -0.094 & 0.257 & -0.113 & 0.391 \\
CG & - & - & -0.049 & 0.131 & - & - \\
MACG & - & - & -0.164 & 0.221 & - & - \\
OC & - & - & - & - & 0.057 & 0.533 \\
MAOC & - & - & - & - & 0.169 & 0.592 \\
Size & 0.004 & 0.427 & 0.007 & 0.162 & 0.003 & 0.509 \\
BM & 0.002 & 0.365 & 0.002 & 0.396 & 0.002 & 0.360 \\
SG & 0.071 & 0.229 & 0.069 & 0.228 & 0.094 & 0.109 \\
LEV & 0.003 & 0.843 & 0.003 & 0.839 & 0.002 & 0.898 \\
\hline
\end{tabular}


Table 5 shows that each variable in the three models has a tolerance value $>0.5$ and a VIF value $<10$. These results can be interpreted that there was no multicollinearity in the three regression models.

Table 5. Multicollinearity Results

\begin{tabular}{lcccccc}
\hline \multirow{2}{*}{ Variables } & \multicolumn{2}{c}{ Model 1 } & \multicolumn{2}{c}{ Model 2 } & \multicolumn{2}{c}{ Model 3 } \\
& Tolerance & VIF & Tolerance & VIF & Tolerance & VIF \\
\hline MA & 0.942 & 1.062 & 0.692 & 1.444 & 0.287 & 3.487 \\
CG & - & - & 0.684 & 1.462 & - & - \\
MACG & - & - & 0.523 & 1.911 & - & - \\
OC & - & - & - & - & 0.654 & 1.530 \\
MAOC & - & - & - & - & 0.262 & 3.816 \\
Size & 0.915 & 1.093 & 0.781 & 1.281 & 0.886 & 1.128 \\
BM & 0.903 & 1.107 & 0.813 & 1.123 & 0.894 & 1.118 \\
SG & 0.984 & 1.016 & 0.279 & 1.017 & 0.984 & 1.016 \\
LEV & 0.916 & 1.092 & 0.988 & 1.108 & 0.911 & 1.097 \\
\hline
\end{tabular}

Result and Discussion

Table 6. Hypotheses Testing

\begin{tabular}{lccc}
\hline Model & Coefficient & Sig. & Decision \\
\hline MA -> EQ & -0.377 & 0.002 & $\mathrm{H}_{1}$ Accepted \\
MA*CG -> EQ & 0.448 & 0.049 & $\mathrm{H}_{2}$ Accepted \\
MA*OC -> EQ & 0.145 & 0.785 & $\mathrm{H}_{3}$ Rejected \\
\hline
\end{tabular}

Table 6 show that there are 2 of 3 hypotheses statement that can be accepted and has similar findings to the previous studies. This study support previous study by Djuitaningsih \& Rahman (2012) which stated that there is a relationship between the ability of management and the quality of earning $\left(\mathrm{H}_{1}\right)$ in a negative way which means that the more-able manager is, the more competent they are to produce fewer earnings quality, vice versa. The significant values of the relationship between managerial ability and earnings quality were lower than 0.050 (0.002) which means that $\mathrm{H}_{1}$ is accepted. Table 7 shows that the mean score of managerial ability that is close to the value of $1(0.794)$ means that the respondent in this study can be classified as high managerial ability. On the other side, the mean score of earnings quality that is far below the value of $1(0.094)$ means that there is a low level of the 
Does managerial ability enhance earnings quality? The moderating role of corporate governance quality and ownership concentration by Fitri Romadhon, Indra Wijaya Kusuma

quality of earnings in this study. Therefore, it can be concluded that the more proficient a manager is, the lower the accrual quality will be.

Table 7. Descriptive Statistics

\begin{tabular}{lcc}
\hline Model & Mean & Std. Deviation \\
\hline EQ & .0938 & .1211 \\
MA & .7944 & .25211 \\
CG & -.0023 & .62102 \\
OC & .5018 & .23362 \\
Size & Rp5,065,723,133 & 3.74958 \\
BM & .3192 & 7.73835 \\
SG & .0924 & .29405 \\
LEV & 1.0880 & 1.23333 \\
\hline
\end{tabular}

The results of this study can also be explained using agency theory. Managers may act opportunistically because they get more information than principals; managers have flexibility in choosing accounting methods as the flexibility of accounting standards allows managers to determine the method to be used from several alternatives. The negative influence of reputable managers on earnings quality also can be explained by the rent extraction hypothesis, which states that managers with more reputations are more likely to use their authority to manipulate earnings to maintain capital market perceptions (Djuitaningsih \& Rahman, 2012; Abbadi et al., 2016; SeTin \& Murwaningsari, 2018). Crossland \& Hambrick (2007) argues that the size of the manager's influence depends on managerial discretion, which itself is determined by organizational factors, meaning that when managers are in an environment that lacks limiting authority, the negative effect on earnings quality can be increasingly strong.

This study also proved Mersni \& Ben Othman (2016) and Marchini et al. (2018) argument which stated that the corporate governance quality will enhance the relationship between managerial ability and the quality of earnings $\left(\mathrm{H}_{2}\right)$. The significant values of the relationship between managerial ability and earnings quality with corporate governance play as moderators' role were slightly lower than $0.050(0.049)$ which means that $\mathrm{H}_{2}$ is accepted. It suggested that the corporate governance quality can strengthen the relationship between managerial ability and earnings quality because the existence of corporate governance is expected to limit the opportunistic behavior of increasingly proficient managers. These results confirm that the inconsistency of previous research results can be caused by other 
factors that can affect the relationship between managerial ability and earnings quality, one of which is the supervisory mechanism embodied in corporate governance quality. What is meant by the supervisory mechanism of corporate governance is that the board of commissioners functions to supervise managers, including in the case of asset misuse. The audit committee also plays a role in monitoring the effectiveness of internal control and the quality of financial reports, ensuring company compliance with regulations (Man \& Wong, 2013). To ascertain whether the presence of the board of commissioners and the audit committee has been effective, the number of meetings is an appropriate indicator to assess the proficiency of the governance structure in controlling manager behavior.

Each component of corporate governance when combined as corporate governance quality is proven to play an important role in explaining the relationship between managerial ability and earnings quality. As explained by Crossland \& Hambrick (2007) study that confirms that the influence of managers on companies depends on the authority they have, and this authority can be influenced by organizational factors, such as strong or weak corporate governance. The results of this study are also inseparable from the process of improving corporate governance quality in Indonesia. Besides, the corporate governance assessment report published by Asian Development Bank (2014) states that several companies in Indonesia recorded an increase in their scores, from 84.39 points in 2013 to 91.98 points in 2014. An example is a case that occurred at PT. Garuda Indonesia, where the board of commissioners carried out supervision by refusing to approve the earnings results recorded in the financial statements. This situation indicates that managers have the power to control financial reports with their authority to determine accounting methods, and this authority will be reduced or limited by the supervision of the commissioners who act as part of corporate governance.

Finally, unlike (Li et al., 2015; Huang \& Xue, 2016; Bao \& Lewellyn, 2017; Lassoued et $a l ., 2018$ ) whom all stated that ownership concentration can enhance the relationship between managerial ability and earnings quality, this study concluded the opposite. The role of ownership concentration as moderator factors between the relationship of managerial ability and earning quality failed to prove in this study. The significant values of the relationship between managerial ability and earnings quality with corporate governance as moderators were higher than $0.050(0.785)$ which means that $\mathrm{H}_{3}$ is rejected. A possible explanation for this result is the lack of incentives for shareholders to actively supervise the managers, as stated by (Jung \& Kwon, 2002) research that not all shareholders have an incentive to 
Does managerial ability enhance earnings quality? The moderating role of corporate governance quality and ownership concentration by Fitri Romadhon, Indra Wijaya Kusuma

supervise management. The reason could be because their skills are lacking, they are constrained by free-rider problems, or they control managers according to their interests.

In the Indonesian context, not all majority of shareholders have expertise in supervision or fully understand the technical conditions of the company. One example is PT. Intikeramik Alamsari Industri, which is engaged in the building products industry, whose majority of shares were owned by PT. Inti Karya Megah, which is an automotive company. Apart from adequate representation of the parties involved in the corporate governance mechanism, the supervisory role of the owners is also limited to certain forums, such as the annual General Meeting of Shareholders (GMS) or other meetings that are not regularly held.

\section{Conclusion and Suggestion}

This study was conducted to re-examine the effect of managerial ability on earnings quality by including corporate governance quality and ownership concentration as factors that are expected to be able to explain the inconsistencies in the results of previous studies. This study succeeds in proving the moderation role of governance quality in strengthening the relationship between managerial ability and earnings quality. However, the role of ownership concentration as a moderator factor failed to prove in this study. A possible explanation for this result is the lack of incentives for shareholders to actively supervise the managers. Interestingly, there is a negative effect between managerial ability and earnings quality. The opportunistic actions by managers who want to meet their performance targets were considered as the main reason for these negative influences.

The implication of this research for the company is that it can function as a consideration in manager performance assessment, especially in the managerial ability aspect, and as a consideration in choosing managers who are not only proficient but also able play a role in aligning organizational goals and maximizing the welfare of stakeholders. Besides, this research can encourage regulators to evaluate the effectiveness of the implementation and formulation of corporate governance policies. Among the limitations of this study is the measurement of the DEA score for managerial ability was limited to the manufacturing industry and used inputs and outputs that were not following the measurements proposed by previous studies. Also, the data obtained were limited and the measurement of governance only consisted of a few components. Suggestions for future research are that they consider ethical factors in managers and use several measures of earnings quality, such as earnings persistence and earnings management, and samples from industries other than the manufacturing industry. 


\section{References}

Abbadi, S., Hijazi, Q., \& Al-Rahahleh, A. (2016). Corporate governance quality and earnings management: Evidence from jordan. Australasian Accounting, Business and Finance Journal, 10(2), 54-75. https://doi.org/10.14453/aabfj.v10i2.4

Bao, S. R., \& Lewellyn, K. B. (2017). Ownership structure and earnings management in emerging markets-An institutionalized agency perspective. International Business Review, 26(5), 828-838. https://doi.org/10.1016/j.ibusrev.2017.02.002

Bertrand, M., \& Schoar, A. (2003). Managing with style: The effect of managers on firm policies. The Quarterly Journal of Economics, 118(4), 1169-1208. https://doi.org/10.1162/003355303322552775

Bertrand, Marianne, \& Mullainathan, S. (2003). Enjoying the quiet life? Corporate governance and managerial preferences. Journal of Political Economy, 111(5), 10431075. https://doi.org/10.1086/376950

Bolmiri, S. H., Gardoon, A., \& Kahkesh, P. H. (2016). Study of the effect of management ability on earnings quality. International Journal of Management, Accounting and Economics, 3(5), 319-335.

Bonsall, S. B., Holzman, E. R., \& Miller, B. P. (2017). Managerial ability and credit risk assessment. Management $\quad$ Science, 63(5), 1425-1449. https://doi.org/10.1287/mnsc.2015.2403

Bryan, D., Liu, M. H. C., Tiras, S. L., \& Zhuang, Z. (2013). Optimal versus suboptimal choices of accounting expertise on audit committees and earnings quality. Review of Accounting Studies, 18(4), 1123-1158. https://doi.org/10.1007/s11142-013-9229-8

Cohen, J. R., Hoitash, U., Krishnamoorthy, G., \& Wright, A. M. (2014). The effect of audit committee industry expertise on monitoring the financial reporting process. The Accounting Review, 89(1), 243-273. https://doi.org/10.2308/accr-50585

Crossland, C., \& Hambrick, D. C. (2007). How national systems differ in their constraints on corporate executives: a study of CEO effects in three countries. Strategic Management Journal, 28(8), 767-789. https://doi.org/10.1002/smj.610

Dechow, P., Ge, W., \& Schrand, C. (2010). Understanding earnings quality: A review of the proxies, their determinants and their consequences. Journal of Accounting and Economics, 50(2-3), 344-401. https://doi.org/10.1016/j.jacceco.2010.09.001

Dechow, P. M., \& Dichev, I. D. (2002). The quality of accruals and earnings: The role of accrual estimation errors. The Accounting Review, 77(s-1), 35-59. 
Does managerial ability enhance earnings quality? The moderating role of corporate governance quality and ownership concentration by Fitri Romadhon, Indra Wijaya Kusuma

https://doi.org/10.2308/accr.2002.77.s-1.35

DeFond, M. L. (2010). Earnings quality research: Advances, challenges and future research. Journal of Accounting and Economics, 50(2-3), 402-409. https://doi.org/10.1016/j.jacceco.2010.10.004

Demerjian, P. R., Lev, B., Lewis, M. F., \& McVay, S. E. (2013). Managerial ability and earnings quality. The Accounting Review, 88(2), 463-498. https://doi.org/10.2308/accr50318

Demsetz, H., \& Lehn, K. (1985). The structure of corporate ownership: Causes and consequences. Journal of Political Economy, 93(6), 1155-1177. https://doi.org/10.1086/261354

Dichev, I. D., Graham, J. R., Harvey, C. R., \& Rajgopal, S. (2013). Earnings quality: Evidence from the field. Journal of Accounting and Economics, 56(2-3), 1-33. https://doi.org/10.1016/j.jacceco.2013.05.004

Djuitaningsih, T., \& Rahman, A. (2012). Pengaruh kecakapan manajerial terhadap kinerja keuangan perusahaan. Media Riset Akuntansi, 1(2).

Fan, J. P. ., \& Wong, T. . (2002). Corporate ownership structure and the informativeness of accounting earnings in East Asia. Journal of Accounting and Economics, 33(3), 401425. https://doi.org/10.1016/S0165-4101(02)00047-2

García Lara, J. M., Osma, B. G., \& Neophytou, E. (2009). Earnings quality in ex-post failed firms. Accounting and Business Research, 39(2), 119-138. https://doi.org/10.1080/00014788.2009.9663353

Ge, W., Matsumoto, D., \& Zhang, J. L. (2011). Do CFOs have style? An empirical investigation of the effect of individual CFOs on accounting practices. Contemporary Accounting Research, 28(4), 1141-1179. https://doi.org/10.1111/j.19113846.2011.01097.x

Gul, F. A., Fung, S. Y. K., \& Jaggi, B. (2009). Earnings quality: Some evidence on the role of auditor tenure and auditors' industry expertise. Journal of Accounting and Economics, 47(3), 265-287. https://doi.org/10.1016/j.jacceco.2009.03.001

Harris, O., Karl, J. B., \& Lawrence, E. (2019). CEO compensation and earnings management: Does gender really matters? Journal of Business Research, 98, 1-14. https://doi.org/10.1016/j.jbusres.2019.01.013

Huang, X. (Sharon), \& Sun, L. (2017). Managerial ability and real earnings management. Advances in Accounting, 39, 91-104. https://doi.org/10.1016/j.adiac.2017.08.003

Huang, Z., \& Xue, Q. (2016). Re-examination of the effect of ownership structure on 
financial reporting: Evidence from share pledges in China. China Journal of Accounting Research, 9(2), 137-152. https://doi.org/10.1016/j.cjar.2015.11.001

Jensen, M. C., \& Meckling, W. H. (1976). Managerial behavior, agency costs and ownership structure. Journal of Financial Economics, 3(4), 305-360.

Jung, K., \& Kwon, S. Y. (2002). Ownership structure and earnings informativeness. The International Journal of Accounting, 37(3), 301-325. https://doi.org/10.1016/S00207063(02)00173-5

Klein, A. (2002). Audit committee, board of director characteristics, and earnings management. Journal of Accounting and Economics, 33(3), 375-400. https://doi.org/10.1016/S0165-4101(02)00059-9

Lassoued, N., Attia, M. B. R., \& Sassi, H. (2018). Earnings management in islamic and conventional banks: Does ownership structure matter? Evidence from the MENA region. Journal of International Accounting, Auditing and Taxation, 30, 85-105. https://doi.org/10.1016/j.intaccaudtax.2017.12.003

Le Breton-Miller, I., Miller, D., \& Bares, F. (2015). Governance and entrepreneurship in family firms: Agency, behavioral agency and resource-based comparisons. Journal of Family Business Strategy, 6(1), 58-62. https://doi.org/10.1016/j.jfbs.2014.10.002

Li, K., Lu, L., Mittoo, U. R., \& Zhang, Z. (2015). Board independence, ownership concentration and corporate performance-Chinese evidence. International Review of Financial Analysis, 41, 162-175. https://doi.org/10.1016/j.irfa.2015.05.024

Lobo, G. J., \& Zhou, J. (2001). Disclosure quality and earnings management. Asia-Pacific Journal of Accounting \& Economics, 8(1), 1-20. https://doi.org/10.1080/16081625.2001.10510584

Man, C. K., \& Wong, B. (2013). Corporate governance and earnings management: A survey of literature. Journal of Applied Business Research, 29(2), 391-418. Retrieved from https://ssrn.com/abstract=3003835

Marchini, P. L., Mazza, T., \& Medioli, A. (2018). The impact of related party transactions on earnings management: some insights from the Italian context. Journal of Management and Governance, 22(4), 981-1014. https://doi.org/10.1007/s10997-018-9415-y

McNichols, M. F. (2002). Discussion of the quality of accruals and earnings: The role of accrual estimation errors. The Accounting Review, 77(s-1), 61-69. https://doi.org/10.2308/accr.2002.77.s-1.61

Mersni, H., \& Ben Othman, H. (2016). The impact of corporate governance mechanisms on earnings management in Islamic banks in the Middle East region. Journal of Islamic 
Does managerial ability enhance earnings quality? The moderating role of corporate governance quality and ownership concentration by Fitri Romadhon, Indra Wijaya Kusuma

Accounting and Business Research, 7(4), 318-348. https://doi.org/10.1108/JIABR-112014-0039

Murniati, M., Sa'diyah, M., \& Subadriyah, S. (2019). Hermeneutics of earning management: Between pressure and opportunity. JEMA: Jurnal Ilmiah Bidang Akuntansi Dan Manajemen, 16(1), 46. https://doi.org/10.31106/jema.v16i1.1666

Pan, Y., Wang, T. Y., \& Weisbach, M. S. (2015). Learning about CEO ability and stock return volatility. The Review of Financial Studies, 28(6), 1623-1666. https://doi.org/10.1093/rfs/hhv014

Piot, C., \& Janin, R. (2007). External auditors, audit committees and earnings management in France. European Accounting Review, 16(2), 429-454. https://doi.org/10.1080/09638180701391030

Pomeroy, B., \& Thornton, D. B. (2008). Meta-analysis and the accounting literature: The case of audit committee independence and financial reporting quality. European Accounting Review, 17(2), 305-330. https://doi.org/10.1080/09638180701819832

Prakoso, G., \& Purwanto, A. (2017). Pengaruh pemilihan kantor akuntan publik dan karakteristik manajemen terhadap manajemen laba. Diponegoro Journal of Accounting, 6(1), 128-140.

SeTin, S., \& Murwaningsari, E. (2018). The effect of managerial ability towards earning quality with audit committee as moderating variable. Journal of Business and Retail Management Research, 12(3).

Shette, R., Kuntluru, S., \& Korivi, S. R. (2016). Opportunistic earnings management during initial public offerings: evidence from India. Review of Accounting and Finance, 15(3), 352-371. https://doi.org/10.1108/RAF-03-2015-0048

Shleifer, A., \& Vishny, R. W. (1997). A survey of corporate governance. The Journal of Finance, 52(2), 737-783. https://doi.org/10.1111/j.1540-6261.1997.tb04820.x

Sousa, E. F. de, \& Galdi, F. C. (2016). The relationship between equity ownership concentration and earnings quality: evidence from Brazil. Revista de Administração, 51(4), 331-343. https://doi.org/10.1016/j.rausp.2016.07.006

Susilawati, D., \& Rakhman, F. (2018). The effect of ownership structure and investor protection to firm value: Analyst following and as moderating variable. Jurnal Akuntansi Dan Investasi, 19(1), 64-75. https://doi.org/10.18196/jai.190192 